\title{
A Legal Evaluation of Nigeria's Electoral Jurisprudence
}

\author{
Victor Nonso Enebeli, PhD* \\ David Chibuike Njoku**
}

\begin{abstract}
The practice of conducting elections in Nigerian politics dates back to Pre-Independence particularly, after the enactment of the Clifford Constitution of 1922. After Nigeria's independence from British colonial rule in 1960, the Nation prides herself as a democratic Nation regardless of the 13 years of military interference. This, she tends to demonstrate by conducting periodic Elections every four years to select leaders. This exercise is made possible by virtue of the existence of some legal frameworks which set Electoral modalities and guidelines for effective electioneering. Some of these laws as will be expansively discussed in chapter three of this research established INEC and empowered it to function as the main Electoral Umpire; and also, at most one independent Electoral Commission in each state of the Federation. These laws laid down rules and regulations guiding the activities of these Electoral Bodies and candidates prior, during and after the Elections. The 1999 Constitution for instance recognizes the existence of INEC and its functions, saddled it with some responsibilities and made provisions for qualifications, disqualification and tenures of candidates. It suffices to say that the coffers of the Nation is seriously affected each time Election is to be conducted given that the exercise is capital intensive. In spite of the money spent, the deafening echoes of unfree, unfair and incredible Election keep reverberating throughout the nooks and crannies of the country. There have been allegations that most, if not all of Nigerian Electoral experience is characterized by broad day light rigging, favoritism, ethnicity complicity by Electoral Umpire, thuggery, intimidation using State and non-state actors. What this ultimately show is sheer noncompliance with these laws. In any case, it is believed, that is the reason our courts are inundated with countless Electoral Petitions. The Courts have never failed in their roles of shaping the Nigerian democractic and political landscape, using judicial powers and pronouncements, especially where there exist an area not covered by law. Conclusively, this research recommends the implementation of the 2008 Uwais Electoral Reform Committee Report.
\end{abstract}

Keywords: Legal, Election, Jurisprudence, Nigeria

DOI: $10.7176 / \mathrm{JLPG} / 118-01$

Publication date: February $28^{\text {th }} 2022$

\subsection{Introduction}

The world is fast moving from the government of institutional monarchy and archaic oligarchy; to a liberal democracy. Most Countries all over the world, Nigeria inclusive, practice democracy one way or the other. It's this democracy that enables the governed to have a say in the scheme of things, thus being the architect, the ultimate determinant of who would or who wouldn't be. Since it's not possible for every citizen to be directly involved in governmental affairs of his/her country, at the same time; it then means that they should be able to air their views through delegated representatives. This is a necessary condition for obtaining the consent of the governed in any authority. ${ }^{1}$ Democracy enables the ruled to choose who rules over them and superintend the collective resources and powers of the state. The process through which the above discussed choice is made possible is through periodic Elections. The above establishes that there is an organic link between democracy and elections. For this linkage to be productive, it has to meet certain essential conditions. These conditions include: the people have to be empowered to make political choice without hindrance, and the political atmosphere under which this choice is made should be free from threat, intimidation and manipulation. Nigeria being a democratic Nation has carried out quite a number of Elections and is set to carry out another as 2023 draws close, and there is mixed feelings as to whether the conditions outlined above will be met. Laws being the framework upon which any phenomenon or factor is premised, was developed to ensure the free and fair conduct of Elections in Nigeria, and this long essay aims at reviewing these laws and how effective they have been in taming the menace of Election Malpractice and Electoral Irregularities. Nigeria has had a chequered history of electoral crises starting from the very first republic. Thus, it became imperative for the Nation Nigeria to make some laws that will moderate the Electoral Processes in Nigeria and at the same time curb Electoral Violence. The current clamour is for the National Assembly to tilt the pendulum towards the side of electronic voting. This long essay aims at giving a critical appraisal of these laws in order to see how they can be improved to guarantee

\footnotetext{
* Victor Nonso Enebeli, Esq. LLB(Hons)(London Met), LLM \& PhD(Coventry), B.L.,(Abuja), MCIArb (UK), Lecturer, Faculty of Law, Rivers State University, Port Harcourt, Rivers State. Email Address: victor.enebeli@yahoo.co.uk. Phone No: 09020176657

** David Chibuike. Njoku, Esq. LL.M (RSU) in-view; BL (Abuja); LL.B (UK); Dip-in-Law (UK), ACIArb (UK) Senior Associate Tuduru Ede, SAN \& Co. Port Harcourt, Rivers State, Nigeria. Email address: david.chibuike22@yahoo.com 08065357894, 08052339985

${ }^{1}$ Umar A. Dubagari, 'The rule of Law and Electoral Process in Nigeria: A critical Reflection', [2017] (6) (6), Global Journal of Interdisciplinary Social Sciences.
} 
a hitch free election during subsequent exercises.

\subsection{Conceptual Framework \\ 2.0.1 Election}

Social contract theory says that people live together in society in accordance with an agreement that establishes moral and political rules of behavior. For a philosopher like Hobbes, he believes that in the time when men were not governed by law, or have a leader to lead them, life was solitary, brutish, nasty and short ${ }^{1}$. Thomas Hobbes puts it thus that life was "a war of everyman against every man"2. Hence it became necessary for people to gather, harness their powers to hand over to a single entity who shall be in charge of these power and attendant resources for the benefit of all. So the people installed a Government on ground, and in keeping faith with this practice, the acceptable means of doing this especially in modern democracy is through periodic Elections.

Election as a practice, is an age long ritual that entails a set of people chosing who will rule or govern them. Elections started in the medival period and there are strong indications that the ritual was developed in ancient Rome and Greek city states like Athens, used when choosing an Emperor over an empire. Liberal democratic theories attribute special authority to the amalgamation of the expressed preferences of individuals through recognized procedures. They reject the idea that social choice can be made by some kind of group mind or interpersonal entity built out of individuals but different from them in kind ${ }^{3}$. Election is defined as the formal process of selecting a person for public office or of accepting or rejecting a political proposition by voting ${ }^{4}$. It is the process of selecting a person to occupy an office, usually a public office ${ }^{5}$. Election is the process of choosing a person or a group of people for a political position through the instrumentality of voting ${ }^{6}$. It's also defined as the process or act of choosing people for office, especially political office, by taking votes ${ }^{7}$. Election can be a right or a duty and the act, of choosing ${ }^{8}$. The selection of one man from among several candidates to discharge certain duties in a state, corporation, or society ${ }^{9}$. Thus any Election held under the Act and which includes referendum is known as Election ${ }^{10}$. The definitions above indicate is that Election affords citizens of any Democratic Nation, the ability to chose their leader. It's gained so much notoriety in the psyche of men that is now enshrined in the constitution, not just as of practice but as of rights ${ }^{11}$, enforceable in courts ${ }^{12}$.

\subsubsection{Electoral Umpire}

The concept above in some climes is referred to as the Election Judge but in Nigeria, it's not a Judge it's a body saddled with the responsibility of carrying out Elections. It is defined as a person appointed to supervise Election at the precinct level or a local representative of an election board ${ }^{13}$. Based on our local peculiarities, the legally recognized Electoral Umpire is the Independent National Electoral Commission (INEC) ${ }^{14}$. Thus both the Constitution and the Electoral Act recognizes INEC as the body with the responsibility to register political parties in accordance with the provisions of the Constitution and Act of the National Assembly. It also monitors the organisation and operation of the political parties, including their finances; conventions, congresses, and party primaries. It functions extends to the registering of voters and educating voters on how to exercise their franchise.

\subsubsection{Electoral Dispute}

A Dispute is a conflict or controversy; a conflict of claims or rights; an assertion of a right, claim, or demand on one side, met by contrary claims or allegations on the other ${ }^{15}$. Electoral Disputes can be referred to as any quarrel, misunderstanding or disagreement arising as a result of Elections. Nigeria Elections have never been free from disputes. From the very first republic when the first Elections were held, till this fourth republic, stretching down to 2019 general Elections, all the electioneering process had always been fraught with controversies. Elections disputes manifests itself in different dimensions and usually starts as inter-party bickering, wherein party members of a political party fight themselves over who should be chosen as the party's flagbearer, for the impending Elections. This kind of inharmonious intra-party dispute manifested itself among party members in

\footnotetext{
${ }^{1}$ C.C Wigwe, Jurisprudence and Legal Theory, (Readwide Publishers, 2011) p 244.

2 J Locke, Two Treaties to Government, (vol 1) p 163.

https://www.encyclopedia.com/social-sciences-and-law/political-science-and-government/political-science-terms-and-concepts/election. Last assessed on the 10th day of November 2021.

${ }^{4} \mathrm{https}$ ://www.collinsdictionary.com/dictionary/english/election last assessed on the 10th day of November 2021.

${ }^{5}$ H C Black, Black's Law Dictionary (6th Edition St. Paul Minn. West Publishing Co. 1990) p. 462.

${ }^{6}$ N.C Iwejuo, Elections and Electoral Tribunals in Nigeria, [2011] (5) (2) International Multi-Disciplinary Journal, p 42.

${ }^{7}$ Chambers 21st Century Dictionary (Revised Edition) p 423.

${ }^{8}$ J Burke, Jowitt's Dictionary of English Law(2nd Edition, London Sweet \& Maxwell LTD, 1997) p 686.

${ }^{9}$ Maynard v. District Canvassers, 84 Mich. 228,(1890).

${ }^{10} \mathrm{~s} 156$ of the Electoral Act 2010.

${ }^{11}$ Ss 38, 40, 40 and chapters V and VI of the Constitution of the Federal Republic of Nigeria 1999 as amended.

12 ibid, s 6 (6) a \& b.

13 ibid note 5 , p 464 .

${ }^{14}$ S 15, Part 1 of the Third Schedule of the 1999 Constitution (As Amended); Section 2 of the Electoral Act 2010 (As Amended).

${ }^{15}$ Slaven v. Wheeler, 61 Tex. 654 (1884).
} 
All Progressive Congress (APC) Rivers State Chapter in 2019. Consequently, the dispute botched the party's chances of presenting candidates for different elective positions in the State and Federal levels, except for office of the President which cut across the 36 states of Nigeria ${ }^{1}$. Beyond intra-party conflicts, the disputes continues to campaign periods when the chosen flagbearers of each of the political parties do not just trade words, but go as far as fighting, using political thugs. Causing violence during Election, carrying of ballot boxes and protracted legal battle after the elections ${ }^{2}$.

\subsubsection{Electoral Tribunal}

The Electoral Tribunal is a superior court of record ${ }^{3}$ and was also established by the constitution and vested with the jurisdiction of Electoral Adjudication to the exclusion of all other courts ${ }^{4}$ in Nigeria ${ }^{5}$. Generally a Tribunal is known to have concurrent jurisdiction with State High Courts and Federal High Courts, but in Petitions where the subject matter pertains to Election into the office of the President of Nigeria, the Court of Appeal shall be the Court of first instance ${ }^{6}$, hence the tribunal in that special circumstance. The Tribunal is not a regular court as is obtainable in our everyday legal practice, it's periodic. Thus once it's done with the task for which it was set up, it ceases to exist. A Tribunal is defined as a Court or other adjudicatory body ${ }^{7}$. It's a special court or group of people who are officially chosen, especially by government to examine legal problems ${ }^{8}$. What this means is that a Tribunal is a special kind of court, doing all that a court does but with a specially vested jurisdiction. What this means, as special as the court may appear, it's legally restricted within the precincts of Election matters as any verdict on any other subject matter will be void and of no effect. Put differently, once a Tribunal has discharged it's duties as a Court set up to hear a particular matter, it stops to function. The importance and sacredness of jurisdiction cannot be overemphasized in our legal jurisprudence.

\subsubsection{Democracy}

Democracy, which is derived from the Greek words demos, or people, is defined, basically, as government in which the supreme power is vested in the people. In some forms, democracy can be exercised directly by the people; but in large societies, it is by the people through their elected agents. In the memorable phrase of President Abraham Lincoln, "democracy is government of the people, by the people, and for the people". Democracy is indeed a set of ideas and principles about freedom, but it also consists of practices and procedures that have been molded through a long, but tortuous history. Democracy is the institutionalization of freedom. In the end, people living in a democratic society must serve as the ultimate guardians of their own freedom and must chart a course bearing heavy reliance on the ideals set forth in the preamble to the Constitution of the Federal Republic of Nigeria 1999 as amended and the United Nations Universal Declaration of Human Rights. Recognition of the inherent dignity and of the equal and inalienable rights of all members of the human family is the foundation of freedom, justice, and peace in the world. Democracy may be a word familiar to most, but it is a concept still misunderstood and misused at a time when dictators, single-party regimes, and military coup leaders alike assert popular support by continuously squealing the term democracy. Yet the power of the democratic idea has prevailed through a long and turbulent history, and democratic government, despite continuing challenges, continues to evolve and flourish all around the world. Suffice it be said that the precepts of democracy is now fully rooted in our country today.

Since it's been established that the word democracy comes from the Greek words "demos", meaning people, and "kratos" meaning power; democracy can then be thought of as "power of the people". Thus, it's a way of governing which depends on the will of the people. This is a form of Government in which people choose leaders by voting ${ }^{9}$. Democracy is a system of government in which laws, policies, leadership, and major undertakings of a state or other polity are directly or indirectly decided by the "people". ${ }^{10}$

\subsection{Legal and Institutional Frameworks 3.0.1. National Legal Frameworks}

Since after Nigerian Independence, democracy has always been the model of governance. The most noticeable feature of democracy is periodic election. This affords the citizens the ability to choose a desired Government to be in place and deliver to them the dividends of democracy. It thus follows that any system of government which does not support elections can be anything but democracy. Election is to democracy what jurisdiction is to courts,

\footnotetext{
1 APC v. UMAR \& ORS (2019) LPELR-47296(SC).

${ }^{2}$ Awolowo v Shagari (1979) 6-9 SC, 37; Akeredolu \& Anor v. Mimiko \& Ors (2013) LPELR -20532 (CA); Buhari v. Obasanjo (2005) 13

NWLR (Pt.941)1; Wike V. Peterside \& ors (SC.1002/2015); Amaechi v INEC \& ors (2008) 5 NWLR (Pt.1080) 227.

${ }^{3}$ s 6 (6) of the Constitution of the Federal Republic of Nigeria 1999 as amended.

4 infra s $285(2)$

${ }^{5}$ s 285 of the constitution of the Federal Republic of Nigeria 1999; s 133 of the Electoral Act 2010.

${ }^{6}$ s 239 (1) of the Constitution; s 133 of the Electoral Act 2010; Yesufu v Obasanjo (2004) FWLR (pt. 190) 1383 at 1402.

7 ibid note 5, p 1784, Atiku Abubakar v INEC ((LER [2019] CA/PEPC/002/2019))

${ }^{8} \mathrm{https}$ ://www.google.com/amp/s/dictionary.cambridge.org/amp/english/tribunal last assessed November 17, 2021.

${ }^{9} \mathrm{https}: / /$ www.merriam-webster.com/dictionary/democracy last $17 \mathrm{th}$ November 2021

${ }^{10} \mathrm{https}$ ://www.britannica.com/topic/democracy last assessed 17th of November 2021.
} 
for any attempt to whittle down the voice of the people on the choice who governs them does not only derogate democracy, it damages the foundation of modern civilization. Democracy has lived through ages and thus become the most acceptable model throughout the world. This makes even government which are in form, dictatorial, orligachic or plutocratic, to still proclaim that they rule by the dictates of democracy. Even England that still practices constitutional monarchy, still have a leeway, through which a Prime Minister vested with executive powers of the country can be elected.

\subsubsection{Constitution of the Federal Republic of Nigeria 1999 (CAP C23, LFN 2004)}

The constitution is the first and most important legal framework in Nigeria. It reigns supreme on legal matters throughout the nooks and crannies of the country and it binds all persons and actions of persons throughout the Federation ${ }^{1}$. It can be aptly referred to as a pathfinder, the fulcrum upon which all other laws in Nigeria, hangs. It defines how things should be done, how laws are to be enacted, which legislature can enact what law ${ }^{2}$. On account of its supremacy, if the National Assembly or any other law making body makes any law that runs contrary to the provisions of the constitution that of the constitution shall have overriding effect. The constitution clearly provides that

\section{'If any other law is inconsistent with the provisions of this Constitution, this Constitution shall prevail, and that other law shall, to the extent of the inconsistency, be void'3.}

From the foregoing, one can assert that the constitution is the supreme law, and any other law which rivals the constitution will fall flat and die to the immutable glory of the constitution. This was the case with the recent acquittal of Sen. Orji Uzor Kalu at the supreme court, where S. 396(7) of the Administration of Criminal Justice Act (ACJA) (2015) which allows a judge elevated to the Court of Appeal to sit over a matter at a High Court, clashed with the provisions of SS $249 \& 250$ of the constitution on who can sit as a judge at the Federal High Court. Also in Ogbuanyinya v Obi Okudo the apex court nullified the judgment delivered by Nnaemeka-Agu on June 17, 1977, on grounds that he had already been elevated to the court of appeal before delivering the said judgement. Another instance was exemplified in the case of Inspector General of Police $v$ ANPP and Ors ${ }^{5}$, the court held that the provisions of the Public Order Act which provided that a permit is needed from the Governor before people can assemble in public, is contrary to the provision of the human rights of freedom of expression and association which is contained in SS $39 \& 40$ of the 1999 constitution. Therefore, the provisions of the Public Order Act were held by the court to be unconstitutional, null and void to the extent of their inconsistencies. Similarly, in Benjamin v Kalio ${ }^{6}$, the Supreme Court held that Evidence is the 23rd item provided for in the exclusive legislative list, hence the Rivers State House of Assembly lacks the legislative competence to enact on it. The Supreme Court on the same hand invalidated section 20 of the Land Instruments (Preparation and Registration) law of Rivers State ${ }^{7}$. The Constitution also directs that the activities of political parties shall conform with the provisions of Chapter Two of the Constitution ${ }^{8}$. However, this provision in S 224 is flawed because of its non justiciability embedded in S 6(6) c of the Nigerian Constitution. One wonders why the Constitution mandates Political Parties to confirm to a provision over which the Court cannot have jurisdiction. Given that the Constitution has been established to be the principal legislation in the country. It is worthy of note to state that its supremacy touches down to matters concerning Elections, thus it makes provisions for the election into the office of the President and requisite qualifications ${ }^{9}$, the Governor of any State $^{10}$, National Assembly ${ }^{11}$ and State Assemblies ${ }^{12}$. It's the Constitution also which by its provision established the Independent National Electoral Commission ${ }^{13}$. Thus, this shows that the Constitution recognizes the establishment of INEC and thus saddles it with some supervisory roles regarding the activities of political parties ${ }^{14}$. In the same vein, the Constitution recognizes the presence and existence of political parties ${ }^{15}$, their activities and functions ${ }^{16}$.

\footnotetext{
${ }^{1}$ s 1 (1) \& (2) of the Constitution of the Federal Republic of Nigeria, 1999 as amended.

${ }^{2}$ Benjamin v Kalio (2018) 15 NWLR (Pt. 1641) p 38.

3 ibid.

4 (1979) All NLR 105, (1979)6-9 SC 32.

5 (2007) 18 NWLR (pt. 1066) 457.

${ }^{6}$ Supra.

${ }^{7}$ Cap. 74, of the 1999, Laws of Rivers State. S 20 of the Land Instrument (Preparation and Registration) law of Rivers State provides that no unregistered documents dealing with land shall be admissible in court upon being tendered to prove ownership. Okoye v. Dumez (Nig) Ltd (1985)1 NWLR (Pt.4) 783

${ }^{8}$ s 224 of the Constitution 1999 as amended; the Political and Electoral Objectives of the country is in another breadth, is concerned with election and political objectives of the country is $\mathrm{s} 15$.

${ }^{9} \mathrm{~s} 131$ of the Constitution of the Federal Republic of Nigeria 1999 as amended.

${ }^{10} \mathrm{~s} 171$.

${ }^{11} \mathrm{~s} 66$.

${ }^{12} \mathrm{~s} 106$.

${ }^{13} \mathrm{~s} 153$ (1) f of the Constitution.

${ }^{14} \mathrm{~s} 226$.

15 ss 221 and 222.

16 ss 223 and 224
} 


\subsubsection{The Electoral Act 2010}

The Electoral Act was enacted by the National Assembly pursuant to several provisions of the Constitution ${ }^{1}$. The current Electoral Act was originally enacted in 2006 but was amended in 2010, hence is now known as the Electoral Act 2010. It's the second most important document in the Nation dealing with Elections after the Constitution. Part one of the Act provides for the establishment and functions of the Independent National Electoral Commission.

With regards to election processes, the Act provides under S 9 that the Commission shall compile, maintain and update continuously a National Register of voters for each State and the Federal Capital Territory and Local Government, which will include the names of all persons entitled to vote in any Federal, State, Local Government or Area Council elections in Nigeria. S 9(5) of the Act provides that the registration of voters, updating and revision of the register of voters shall stop not later than 30 days before any election in Nigeria, and the registration shall take place at registration centers designated for that purpose and shall be communicated to the general public by the Commission. S 12 of the Act further provides for the qualification of persons to be registered as a voter in the National Register of Voters. These qualifications are;

The applicant must be a citizen of Nigeria;

The applicant is 18 years and above;

$\mathrm{He}$ is an ordinary resident, works in, originates from the Local Government/Area Council or Ward covered by the registration center;

He presents himself to the registration officers of the Commission for registration as a voter and;

$\mathrm{He}$ is not subject to any legal incapacity such as insanity, to vote under any law, rule, or regulation in force in Nigeria.

A voter is prohibited from registering in more than one registration center or even registering more than once in the same center, the Act provides under S 12 (3) that anyone who contravenes this provision commits an offense and is liable to pay a fine not exceeding N100,000 (One Hundred Thousand Naira) or imprisonment not exceeding one year. The Act also provides for modalities for conducting elections in Nigeria, S 25 that the days of an election in Nigeria will hold on a date decided by INEC by the Constitution. Part IV which ranges from SS 25 to 77 makes provisions for procedures of Election. S 26 provides that in special circumstances, INEC shall have right to postpone Election. S 27 makes provisions for the announcement of Election results, who shall do so for which position and where. The Commission shall not later than 90 days to the day of Election give notice for the date of Election. S 33 is a bar to the indiscriminate substitution of candidates by political parties. The Act recognizes just two exceptions to the effect that the candidate either dies or withdraws. SS $35 \& 36$ provides respectively for the withdrawal and death of candidates. Any candidate who knowingly allows himself to be nominated by more than one Political Party, shall have his nomination invalidated ${ }^{2}$. The Act talks about primaries $^{3}$ as the only way to nominate a candidate for Election, offences likely to be committed by political parties regarding finances or financing a candidate for Election ${ }^{4}$. SS 95 and 96 prohibits certain Acts during Election Campaign.

It has to be noted that the law-makers are not omniscience devoid of human flaws, thus will be unable to foresee all legislative shortcoming in the Act as to pre-empt electoral crises emanating therefrom. These legislative gaps have manifested itself in different facets on our polity over the years in our country ${ }^{5}$, hence the judges filling the gaps and then making laws by so doing. These gaps or inadequacies are what have led to the frequent calls in not just the amendment of the Constitution, but of the Electoral Act. It's is noted with precision that in chapter 2 above, this work exposes some of these inadequacies and how far the Electoral Act had gone to remedy some of them. One of the gaps in discuss is the arbitrary substitution of names of candidates by political parties $^{6}$. The Electoral Act had just undergone amendment and currently awaiting assent by the President. The amendment bill introduces direct primaries and ward chairmen and secretaries could do that at the ward level; political parties are to appoint returning officers which shall be responsible for final collation of results etc.

\subsubsection{Independent National Electoral Commission (Establishment) Decree No 17 of 1998}

The Body charged with the responsibility of conducting all Elections in Nigeria is the Independent National Electoral Commission otherwise known as INEC. This body could not have come into full operation without a legal framework setting the pace for its smooth running. Nigeria had long chequered history of coup d'etat which overthrows the sitting administration and replaces it with Military Administration. Successive military

\footnotetext{
${ }^{1} \mathrm{~s} 4$. It's also to be noted that National Assembly is empowered by viture of the item 22 listed in the exclusive legislative list to enact laws that shall guide the election into the offices of the President, Governors, and members of the National. The exclusive legislative list is the part I of the second schedule to the Constitution.

2 s 37 of the Electoral Act 2010.

${ }^{3} \mathrm{~s} 87$.

${ }^{4} \mathrm{~s} 88$.

${ }^{5}$ Awolowo v Shagari (1979) 6-9 SC, 37; Amaechi v INEC (2008) 5 NWLR (Pt.1080) 227; Bello v AG Oyo State (2006) NWLR (Pt. 1011)378 2,

${ }^{6}$ S 33 of the Electoral Act 2010.
} 
administrations suspend the Constitution and rule with Decrees. Hence the military administration of Abdulsalami promulgated the INEC decree to enable it be formed, conduct Election that will usher in the New Civilian Government.

S. 1 of the decree established the Commission while S. 2 constituted it holding that the chairman and members shall not be less than 50 and 40 years respectively. Ss 3 and 4 provided for tenure of members and functions of the commission respectively. S 6 of the Act sought to infuse independence in the Commission. The decree by virtue of S 7 sought to limit the rights of the members from contesting an elective position under the 1979 Constitution, within a period of 5 years after leaving the Commission. It's my view that this position of the law can no longer be sustained given the fact that the Decree specifically mentioned the defunct 1979 Constitution. This is because we have a yet recent Constitution which is that of 1999 as amended. Another shortcomings of the Decree is that it is very brief. Its contents raises the suspicion that it was hurriedly packaged, thus lacking in substance. It paid more attention to the constitution of the Commission rather than functions. The good thing is that it has gone through several legislative surgeries and thus it's currently merged with the Electoral Act. This is because the preamble to the Electoral Act 2010 states thus "AN ACT TO REPEAL THE ELECTORAL ACT 2006 AND RE-ENACT THE INDEPENDENT NATIONAL ELECTORAL COMMISSION, REGULATE THE CONDUCT OF FEDERAL, STATE AND AREA COUNCIL ELECTIONS AND FOR RELATED MATTERS, 2010". So it can be correctly said that the laws establishing INEC are the Constitution and the Electoral Act 2010

\subsection{Institutional Framework}

The laws have been put in place, the truth is that the laws cannot in themselves begin to function and make our Electoral Process a hitch free one. These laws have to be practiced and enforced by an appropriate body. The bodies involved are what are now known as the institutions. These institutions also exist by the instrumentality of the laws creating them. The establishment laws create the bodies, constitute them, vest them with powers and functions as well as set the ground running for the proper function of the bodies. This Research shall use the following subheadings to discuss some of those bodies involved in the Nigerian Electoral Processes, their duties, powers and limitations.

\subsubsection{Independent National Electoral Commission (INEC)}

The Independent National Electoral Commission (INEC) is an institution created by the Military Administration of Gen Abdulsalami for the main purpose of conducting elections in order to usher in a new civilian Government. This was made enabled by virtue of the Independent National Electoral Commission (Establishment) Decree no 17 of 1998 . INEC was by that law, formed to be a body corporate with perpetual succession ${ }^{1}$ which can sue and be sued in its corporate name ${ }^{2}$. It also follows that it can hold property on its name.

The establishment of INEC is further strengthened by virtue of S 2 of the Electoral Act 2010. The Constitution also recognizes $i^{3}$, thus saddling it with overt responsibilities ${ }^{4}$ as it affects the Nigerian Electoral System. Part 1 para F of the Third Schedule to the 1999 Constitution as amended particularly at S. 15 saddles INEC with the responsibility of organizing, undertaking and supervision of all Elections to the offices of the President, Vice President, Governor, Deputy Governor, Senate, House of Representatives and States House of Assembly. Monitoring the organization and operation of political parties and their finances. Registration of qualified Voters as well as preparation of Voters' Registers etc.

Similarly the Electoral Act 2010 also recognizes the establishment of INEC $^{5}$, and bequeaths it with additional functions which are complimentary to the ones the Constitution gave it in Part 1, para F of the Third Schedule of the 1999 Constitution (As Amended) to the effect that the Commission shall have powers to:

(a) conduct voter and civic education.

(b) promote knowledge of sound democratic election processes.

(c) conduct any referendum required to be conducted pursuant to the provision of the 1999 Constitution or any other law or Act of the National Assembly ${ }^{6}$. In order to ensure its financial autonomy and total independence, the Act established the Independent National Electoral Commission Fund ${ }^{7}$ and S. 4 makes provisions as to how the money should be expended. S 6 of the Act established office in each State of the Federation including the Federal Capital Territory to which shall perform functions as may from time to time assigned to it by the Commission. The INEC Resident Electoral Commissioner shall be removed by the President only when there had been a $2 / 3$ majority of the members of the Senate praying for his removal for inability to discharge the

\footnotetext{
${ }^{1}$ s 1 (2) a of Independent National Electoral Commission (Establishment) Decree No 17 of 1998 which was reenacted as the Electoral Act 2010.

${ }^{2} \mathrm{~s} 1(2) \mathrm{b}$.

S 153 (1) f of the 1999 Constitution as amended.

${ }^{4}$ Part 1, para F of the Third Schedule of the 1999 Constitution (As Amended).

s 1 of the Electoral Act.

${ }^{6} \mathrm{~s} 2$ of the Electoral Act.

${ }^{7} \mathrm{~s} 3$.
} 
functions of his office ${ }^{1}$. S. 27 provides that the Commission is the only body that can announce Election results ranging from Polling Units, Wards, Local Government, State or Federation. It went ahead to state which of its officers shall do the above and where. It's a statutory provision in S. 28 that each officer of the commission shall upon being appointed swear to an Oath of Neutrality before a High Court in accordance to the Second Schedule to the Electoral Act; this is in order to eschew bias in the course of discharging his duties.

The Commission shall not later than 90 days before the day appointed for holding of an election under this Act publish a notice in each State of the Federation and the Federal Capital Territory-

(a) stating the date of the election; and

(b) appointing the place at which nomination papers are to be delivered ${ }^{2}$.

\subsubsection{State Independent Electoral Commission}

State Independent Electoral Commission is a statutorily recognized the body ${ }^{3}$ saddled with the responsibility of organising and conducting election in a state ${ }^{4}$. It's thus an apolitical institution whose neutrality must not be faulted on any ground by the major electoral stakeholders. Any time the opposite is the case, the election it conducts will lose credibility.

While INEC as explained in the preceding heading, is saddled with the responsibility of conducting elections throughout the Federation for the offices of the President, Governor, House of Senate, House of Representatives and State Assemblies ${ }^{5}$; State Independent Electoral Commission is charged with the responsibility of conducting elections into the different Local Government Councils in Nigeria ${ }^{6}$.

S. 3 Part II of the Third Schedule of the 1999 Constitution of the Federal Republic of Nigeria makes provision for the establishment of State Independent Electoral Commission hereinafter known as SIEC. S. 4 of the constitution stipulates the powers of the State Independent Electoral Commission as to organise, undertake and supervise all elections to local government councils within the state also; to render such advice as it may consider necessary to the INEC on the compilation of and the register of voters in so far as that register is applicable to local government elections in the State.

\subsubsection{Political Parties}

The Constitution of the Federal Republic of Nigeria 1999 as amended made provisions for the formation of political parties within the Nigerian political system. Thus no association, other than a political party, shall canvass for votes for any candidate at any election or contribute to the funds of any political party or to the election expenses of any candidate at an election ${ }^{7}$. Political Party is the name that is given to a voluntary and non-government association formed to propose candidates for office who will work towards being elected. The term Political Party was given statutory definition in S. 229 of the constitution to wit; "'political party' includes any association whose activities include canvassing for votes in support of a candidate for election to the office of President, Vice-President, Governor, Deputy Governor or membership of a legislative house or of a local government council". A political party will not be allowed to operate in Nigeria unless it is registered with $\mathrm{INEC}^{8}$ and its membership is open to people from all parts of Nigeria regardless of place of origin, circumstances of one's birth, sex, religion or ethnic grouping 9 . The constitution of such a party is required to be registered with $\mathrm{INEC}^{10}$ and any alterations of the registered constitution has to be registered with the INEC principal office within thirty days of making such alterations ${ }^{11}$. The name or logo of a particular Political Party shall not contain any information that denotes that it's confined to a particular religion, ethnic entity or geographical area ${ }^{12}$ and the head office of the party must be situate in Abuja ${ }^{13}$.

The Constitution also holds that a political party shall submit to INEC a detailed annual statement of its sources of funds assets and expenditures in such form as the Commission may require ${ }^{14}$. The Constitution went further to charge the all political parties not have any assets outside Nigeria or retain any find or assets sent to it from outside Nigeria ${ }^{15}$. However, where any funds or assets is sent to a political party from outside Nigeria, such funds or assets shall be paid over to the Commission within twenty-one days of its receipt with such information

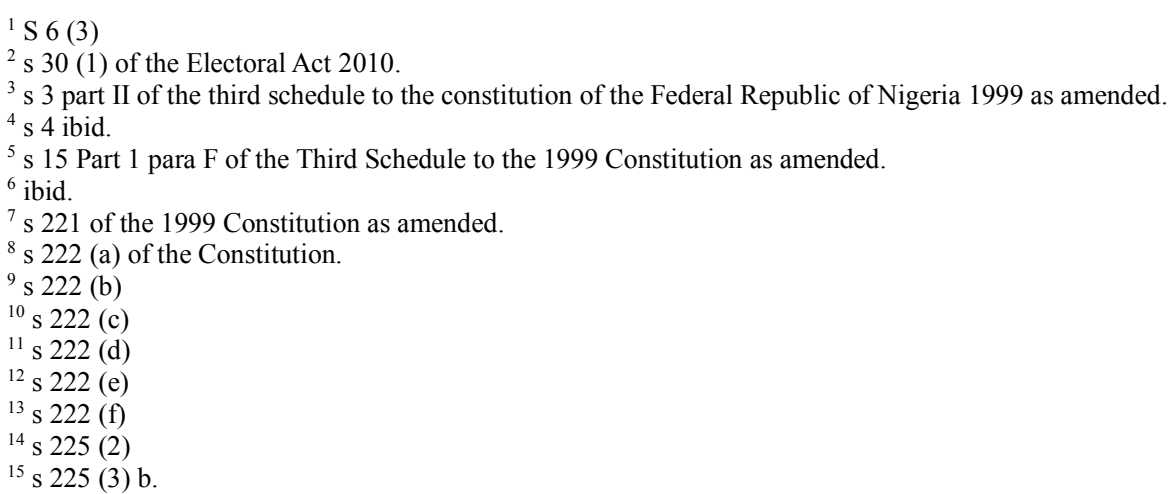


as the Commission may require ${ }^{1}$. Every member of the Commission or its duly authorised agent shall

(a) have a right of access at all times to the books and accounts and vouchers of all political parties; and

(b) be entitled to require from the officers of the political party such information and explanation which to the best of his knowledge and belief are necessary for the purposes of the investigation, the Commission shall state that fact in its report ${ }^{2}$.

In order to nip violence in the bud during Campaign and Elections, the Constitution provides that no association shall organise, train or equip any person or group of persons for the purpose of enabling them to be employed for the use or display of physical force or coercion in promoting any political objective or interest or in such manner as to arouse reasonable apprehension that they are organised and trained or equipped for that purpose $^{3}$. In addition to the rules laid down in the Constitution regarding Political Parties, the Electoral Act 2010 still has some provisions for it.

A political party which has complied with all the provisions of the Constitution and the Electoral Act shall be duly register in so far as such application for registration is not later than 6 months to the date of a general election ${ }^{4}$. The Commission reserves the right to register the symbol of political parties if the proposed symbols passed several tests like not being formally registered by a previously registered political party, not being offensive or objectionable 5 . By virtue of s 85 of the Electoral Act, any political party which wants to engage in congress, convention or conference for the purpose of electing its leaders or choosing its executive, shall notify the Commission in writing no later than twenty-one days to the date of the convention or congress. The Commission reserves the right to inform the political party of its intention to honour or not to honour such invitation to monitor the congress. The Commission is also required to monitor and keep records of the activities of all registered political parties.

\subsubsection{Election Tribunal}

Election Tribunal is under the law recognized as a Court, but it's not a regular Court. It's an adhoc Court usually set up for specific purposes, and having a time frame. Once its duties are dispensed with, the Court automatically ceases to function. It's noted with respect that members of tribunals all over the nation are selected from different courts in Nigeria. Statutorily, Election Tribunal is provided for in the Constitution ${ }^{6}$. It further provided that it shall to the exclusion of any other Court in Nigeria, have jurisdiction to hear and determine all matter and causes arising from Election into the National Assembly; the question as to if the office of any person under this Constitution has ceased; the seat of any person validly elected to the Senate or House of Representatives has been declared vacant; the propriety or otherwise of an electoral petition brought before the Election Tribunal. It's to be noted that there is an exception as to where the cause of action arose as a result of election into the office of the President of the Federal Republic of Nigeria, in such peculiar circumstance, the Appeal Court shall have original jurisdiction ${ }^{7}$. Furthermore, there shall be established in each State of the Federation one or more Election Tribunal to be known as the Governorship and legislative Houses Election Tribunals which shall to the exclusion of all other courts have jurisdiction to entertain and determine matters arising from the election into the office of the Governor and his Deputy, together with the respective National Assembly and State Assembly election for different constituencies ${ }^{8}$. Thus the proper quorum for an Election Tribunal comprises of the Chairman of the Panel and two other members ${ }^{9}$. The Election Tribunal is also a superior court of record ${ }^{10}$. The Electoral Act in S. 140 confers powers on the Election Tribunal to nullify the election of any one who in their opinion was not duly elected and validly returned.

\subsubsection{The Court of Appeal}

The Federal Court of Appeal was set up in 1976 pursuant to the provisions of the Constitution (Amendment) Decree (No. 2) of 1976. The name was changed to the "Court of Appeal" by the Constitution (Suspension and Modification) Decree No. 1 of 1984. The Court of Appeal consists of a President and such number of Justice of the Court of Appeal, not less than 49 of which not less three shall be learned in islamic law and also not less than three shall be learned in Customary law ${ }^{11}$. The Court of Appeal shall be duly constituted if it consists of not less than three Justices of the Court of Appeal ${ }^{12}$. The Supreme Court in the case of Madukolum v Nkemdilim ${ }^{13}$, listed three preconditions which the court must fulfill in order to have jurisdiction over a particular matter viz-

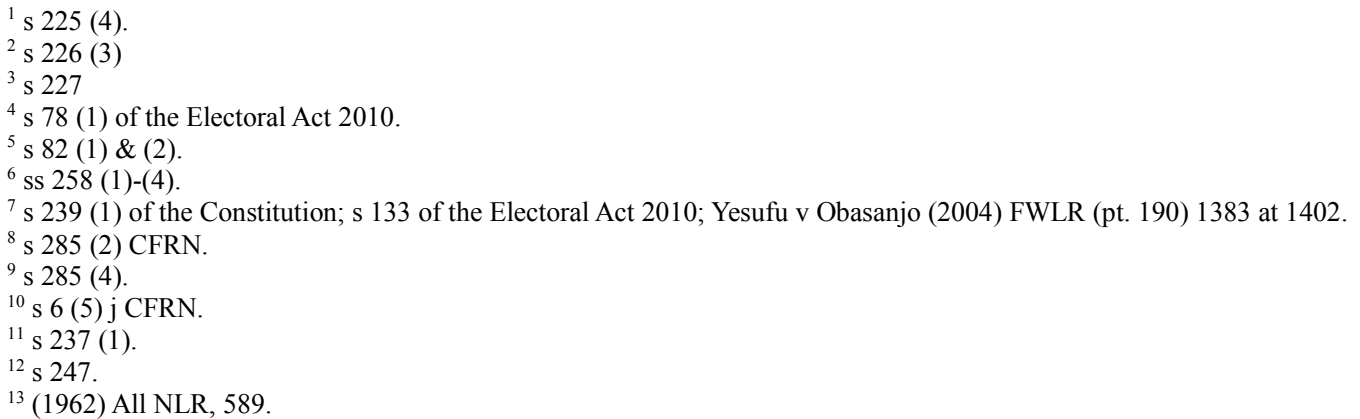


i. it's properly constituted as regards numbers and qualifications of members of the bench and no member is disqualified because of one reason or the other,

ii. the subject matter of the the case is within its jurisdiction, and there is no feature in the case which prevents the court from exercising its jurisdiction,

iii. the case comes before the court initiated by due process of law and upon fulfilment of any condition precedent to the exercise of jurisdiction.

Flowing from the above the Supreme Court set aside the decision of the Court of Appeal in the case of Sokoto State Government \& ors $v$ Kamdex Nigeria Limited ${ }^{1}$, because one of the Justices was absent during hearing the appeal and this negates the provisions of S. 247 (1) of the 1999 Constitution. Generally, the Court of Appeal sits on appellate jurisdiction to hear and determine appeals from Federal High Court, the High Court of the Federal Capital Territory, High Court of State, Sharia Court of Appeal of the Federal Capital Territory, Sharia Court of Appeal of State, Customary Court of Appeal of the Federal Capital Territory, Customary Court of Appeal of State, Tribunals, Court Martial as may be prescribed by an Act of the National Assembly ${ }^{2}$. The Court of Appeal shall to the exclusion of any other Court of law in Nigeria, have original jurisdiction to hear and determine any question as to whether-

a) any person has been validly elected to the office of the President or Vice President under; or

b) the term of the office of the President or Vice President has ceased, or

c) the office of the President or Vice President has become vacant ${ }^{3}$.

So except for matters listed in S. 239 of the Constitution and S. 133 of the Evidence Act, the Court of Appeal sits on appellate jurisdiction on matters arising from all courts in the Federation except of course for the Supreme Court. It's worthy of note that matters pertaining to election petition of the Senate, House of Representatives and House of Assembly terminates at the Court of Appeal.

\subsubsection{The Supreme Court of Nigeria}

The Supreme Court is the Court of final appeal in Nigeria. The motion to having what we now know as Supreme Court now was in 1954 when the Federal Supreme Court was established. However by then, appeal still rose from the Federal Supreme Court to the Judicial Committee of the Privy Council in England. It became the Court of final appeal in 1963 when Nigeria became a Republic and its name was changed to the Supreme Court. The operation of the Supreme Court in our judicial system is made possible by virtue S. 230 of the Constitution and its jurisdiction was conferred by S. 232 of the Constitution of the Federal Republic of Nigeria 1999 as amended. The Supreme Court sits on appeal on all matters coming from the Court of Appeal and terminates therein. This reinforces the popular quote by Justice Chukwudifu Oputa JSC in Adegoke Motors Ltd. v. Adesanya \& Anor ${ }^{4}$

"My simple answer is that it is not part of the jurisdiction or duties of this Court to go on looking for imaginary conflicts. We are final not because we are infallible; rather we are infallible because we are final" 5

Outside the appellate jurisdiction of the Supreme Court, it also exercises original jurisdiction over certain matters. However, before the original jurisdiction of the Supreme Court can be invoked, the suit must disclose the existence of a cause of action and the party must have locus standi ${ }^{6}$. The original jurisdiction of the Supreme Court can only be invoked by a State or the Federal Government when suing in its corporate capacity ${ }^{7}$, and this is vested on it by virtue of S. 232 of the 1999 Constitution. The above section envisages that the original jurisdiction of the Supreme Court arises when there is a dispute between the Federation and any State or States of the Federal Republic as well as if the dispute is between States of the Federation. The Constitution however limits this original jurisdictional competence of the Supreme Court to when the cause of action depends on the question of the existence or extent of a legal right ${ }^{8}$. Furthermore, the Constitution did not shut the door on the original jurisdiction of the Supreme Court, it made a provision which allows the National Assembly to by the instrumentality of future legislations confer on the Supreme Court, such original jurisdiction as it may deem fit. ${ }^{9}$

\subsection{Electoral Challenges, Remedies and Reforms 4.0.1 Challenges of Elections in Nigeria}

The Nigerian Electoral System has never been without challenges or difficulties. Over the years well-meaning Nigerians have been clamouring for good Electoral Process ${ }^{10}$. Others have in different fora suggested series of

\footnotetext{
${ }^{1}$ (2007) 7 NWLR (Pt. 1034) p 43.

${ }^{2}$ s 240 .

3 s 239 .

${ }^{4}$ (1989) 3 NWLR (pt 109) 250

5 Supra@274; SSS v Agbakoba (1999) 3 NWLR (Pt.595)

${ }^{6}$ AG Federation v AG Abia State \& 35 ors (2001) 11 NWLR (Pt. 725) 689; AG Kano State v AG Federation (2007) 6 NWLR (Pt 1029) 164 at 182 .

${ }^{7}$ Osita Nnamani Ogbu, Modern Nigerian Legal System (SNAAP Press Ltd, 3rd Edition) p 228.

${ }^{8}$ s 232 (1) of the Constitution of the Federal Republic of Nigeria 1999 as amended.

${ }^{9} \mathrm{~s} 232(2)$

${ }^{10}$ There has been much clamour for free fair and credible Electoral Process, hence in 2014 during the build up to the 2015 general elections,
} 
Electoral Reforms that will be aimed at remedying our Electoral defects, yet the shortcomings still persists ${ }^{1}$.

This challenges in our Electoral System begins as intra-party rivalry. The selection processes of most political parties, as to who will bear the party flag are mostly flawed. There have been cases of the highest bidder being the person that will grab the party ticket. In a country where money is worshipped and avarice taken as culture, those who have enough money to throw around can easily muscle other contenders and find their way to be the selected flagbearers of the party against meritocracy and popular choice. This is made possible by the system of indirect primaries adopted by most political parties in Nigeria. Since the delegates are not too many, it's easy to buy them or majority of them over with money ${ }^{2}$. It's the powers that be that selects who goes for the party primaries. Prior to the election, puppets have been positioned at several strata of the party, thereby qualifying them as stakeholders and potential delegates. Another challenge bedeviling Electoral Process in Nigeria is Electoral thuggery and violence. During the buildup to Elections in different states across the Nation, violence becomes order of the day. Party thugs usually attack and unleash mayhem on unsuspecting opposing party faithfuls, sometimes these activities result in loss of lives and properties.

\subsubsection{Election Malpractice}

Election Malpractice involves the manipulation of the laws governing the conduct of Elections in favour of a candidate as against others. It involves illegal acts performed by the electoral body, political parties, candidates or the electorate which are capable of influencing the smooth conduct of elections in the country, State or Local Government Council as the case may be. Elections are supposed to in theory and practice to strive towards making democracy 'work', but in many contexts, they fail to embody democratic ideals because they are affected by electoral manipulation and misconduct. When Election Malpractice takes place, a candidate who ordinarily should by the will of the people not win gains an undue advantage over his opponent or other contestants. This goes a long way in hampering the performance of the candidate declared winner in terms of delivery of the dividends of democracy. This concept of Election Malpractice is understood because it manifests through three principal forms: manipulation of the rules governing elections, manipulation of vote preference formation and expression, and manipulation of the voting process. Election Malpractice would be impossible except in connivance with the electoral body. Thus a vote cannot be rigged unless the electoral body permits it. This brings us back to the conundrum of weak institutions in Nigeria, for if the institutions are strong, no candidate will come with influence or affluence to bend the will of the people using the electoral body. There are cases where an INEC returning officer was alleged to have declared a candidate winner under duress. The is also the case wherein armed men and electoral thugs show up at the polling units, hijacked and cart away election materials. These thugs may also decide to intimidate voters, chase members of the other political party away from polling units, or compel them to vote for candidates who they ordinarily would not have voted for. Also, some politicians who are desperate to win the election, print fake results sheets while hiding the original one. After the election, falsified figures are entered into the original one and given to the returning officer to announce under duress or as a mark of financial compromise.

\subsubsection{Vote Buying}

Vote Buying is an activity that involves candidates or party members getting people to vote for them through monetary inducements. The electorate set out wholly to vote a particular candidate based on his or her manifesto, but ends up voting someone else because the new candidate had their choice swayed with overt display of wealth at his disposal. Without the monetary inducements, the electorates would vote for a different candidate. The money are given either before, during or after the election period. It is also noted that often times it's the electorates that leaves their houses to the polling units bearing on mind to cast vote for the highest bidder.

This obviously has an effect on the leadership style of those elected. Once elected under that circumstance, the candidate's focus will be channeled towards recovering the money spent before and during the election. This leaves governance to die, the decay in the system becomes pervasive. The governor sees the governed as having eaten their democratic dividends at the polls.

\subsubsection{Electoral Violence}

Electoral Violence can be seen as instilling reasonable fear or apprehension on candidates and voters alike in other to mechanically change their course of action. Electoral Violence manifests itself in several facets. These facets include but are not limited to using political thugs to intimidate, harass or possibly kill rival candidates, kidnapping, maiming and killing of rival party members, harassing of voters before during and after Election, usage of security agents to beat, intimidate and detain rivals etc.

Tuggery is rampant in the aspect of our youths, today most politicians have tugs whom they use to disrupt

President Goodluck Ebele Jonathan signed an election peace truce with Muhammadu Buhari. A similar act was replicated in 2019 between President Muhammadu Buhari and Atiku Abubakar.

${ }^{1}$ Late President Umaru Musa Yaradua set up an Electoral Reform Committee headed by Rtd Justice Uwais and this Committee released a report in 2008 advising the government on the steps to take in order to jettison the shortcomings Nigerian Electoral System.

2 This appears to be the reason why the Electoral Act Amendment Bill waiting assent by the president contains a provision which made direct primaries compulsory. It's submitted that the above provision will cure the problem of monetary influence and imposition of candidates. 
election and steal ballot boxes from pulling stations, these are jobless youths who are trying to earn a living from dubious antecedents, these are the same youths who they use in carrying out their nefarious activities ranging from political rallies, political assassination etc. ${ }^{1}$

It has to be noted with precision that, violence is a major feature of every single political transition that Nigeria has ever had. Although a lot of factors could be said to be underlying in discussion of the concept of electoral violence in the Nigerian political landscape. Nigeria still looks forward to a transparent electoral system that helps to put in place a peaceful and transparent political transition. As of today global searchlight beams on democratic governance attained through successfully conducted elections that meet international standards set by democratically inclined citizens, and multilateral organizations. This also helps to strength the legitimacy base of those who govern. Since electoral violence with its concomitant effect had been the bane of Nigeria's democratic transition, there has been the need to set in motion a machinery to curb the menace.

\subsubsection{Unavailability of Technology}

Technology refers to methods, systems, and devices which are the result of scientific knowledge being used for practical purposes. The world has long moved towards the side of technology has become a central factor, a fulcrum around which almost everything revolves.

However, the truth is that our Electoral System is yet to be awakened to this incontrovertible reality. The only seeming technology introduced into our Electoral System is the Card Reader whose existence has not even been ratified by the Electoral Act ${ }^{2}$. There had been heated arguments as to which should be upheld over the other. Whether one is subject to the other or they are complimentary to each other. It's submitted in this research that Voters' Register is by our laws ${ }^{3}$, recognized and superior to Card Reader ${ }^{4}$.

Our Electoral System first is supposed to have evolved to adopt, after so many Elections, the technology of voting from homes, electronic voters' register, vote transmitter, voters' counter etc to avoid double voting. If the Nigerian Electoral System goes electronic, the chances that violence will ensue, fraud occur, ballot boxes snatched, people killed, during Election will be significantly reduced or even exterminated. It's disappointing to realise that the amended Electoral Act which recognizes electronic voting is still waiting assent after many months of lying at the president's table.

\subsubsection{Poverty and Ignorance}

Voters' apathy is one challenge that has for so long bedeviled the Nigerian Electoral System. People tend to shy away from going to elect those who will go into elective positions. Voter apathy occurs when eligible voters do not vote in public elections. Outside of election time, voters may seem disillusioned with the political process or politicians in general. In a country supposedly run by elected officials, disenchanted and inactive citizens can present problems. For example, when very few people vote, the politicians elected do not represent the beliefs and values of the general population ${ }^{5}$. Voter apathy has been compared with a sort of political depression, where one feels helpless and unable to influence important events. People fail to note that their votes count, and by refusing to vote in an Election, it becomes impossible for their preferred candidate to win. This creates a leeway through which wrong people get into power. Outside the non fulfilment of electoral promises, another factor that fuels voters' apathy is ignorance to the harm that non-voting can cause.

Also, on this discuss is scourge poverty, it is submitted without prejudice that only those who are smeared with poverty would dare to sell their votes at polling units. This is because they see that as the only opportunity to benefit the common wealth of the masses which the political elites have amassed for themselves. Poverty also makes it easy for the political elites to convince youths to take up arms and become political thugs.

\subsubsection{Corruption}

Corruption erodes trust, weakens democracy, hampers economic development and further exacerbates inequality, poverty, social division and the environmental crisis $^{6}$. Corruption as the abuse of entrusted power for private gain. This occurs where the electoral umpire decides to favour a particular candidate at the expense of others. An electoral body like INEC occupy position of trust and should hold it sacred and shouldn't compromise it for any reason. Sadly the opposite is the case, wherein officers of the Electoral Umpire compromise the trust they bear to help a candidate who otherwise lost, to win the election. This is a frequent occurrence in the Nigerian Electoral System, hence the will of the people as to who rules them becomes subverted. This very happening forms part of the reason why their voters' apathy in this part of our world.

Bribery is another cancan worm that has eaten deep into the electoral system in Nigeria. A lot of people are

\footnotetext{
${ }^{1}$ S. Uwhejevwe-Togbolo, 'Problems of Elections in Nigeria' http://www.gamji.com Accessed 14 ${ }^{\text {th }}$ December, 2021

${ }^{2}$ It's the law that the only document recognized by the Electoral Act for the purpose of Voters' verification is the Voters' Register. The Card Reader was an introduction of INEC through its 2015 guidelines thus unknown to law. Thus whenever there is a conflict between Card Reader and Voters' Register, the later will prevail.

${ }^{3}$ ss 15,16 and 17 of the Electoral Act 2010

${ }^{4}$ Wike V. Peterside \& ors (SC.1002/2015).

${ }^{5} \mathrm{https}$ //study.com/academy/lesson/voter-apathy-definition-statistics-causes.html $>$ last assessed 20th Dec 2021.

${ }^{6} \mathrm{https} / / /$ www.transparency.org/en/what-is-corruption> last assessed on 20th Dec 2021
} 
involve in collecting gratification from politicians thereby selling their conscience and their votes. ${ }^{1}$

\subsection{Reforms}

An Electoral Reform Committee was set up by President Umaru Musa Yaradua and the committee released a report in 2008. The committee was set up to probe into the electoral mischief with a view to coming up with the solutions to electoral flaws in Nigeria. The report demonstrated that free, fair and credible elections are a crucial requirement for good governance and sustainable development in any democratic setting. A plethora of factors have however been identified as hindering the conduct of free, fair and credible elections in Nigeria ${ }^{2}$.

Electoral reform is a transformation of the whole gamut of election administration with a view to providing more opportunity for participation in an environment that is open, competitive and equitable $^{3}$. It's without and iota of doubt that Electoral Reforms remains the platform through which good governance is ensured. This is because citizens who vote during elections are psychologically fulfilled that the emerging political class in governance is theirs and not an imposition and this also guarantees full mobilization of the citizenry towards the attainment of the desired national development. This implies that there is spirit of accountability and ownership that flows from the electorates to the political class in power. As developed as our Electoral System is, that was certainly not the starting point for it. It sure must have passed through some processes, transformation, transition and ultimately remodeling and Nigerans still looks up to more. Hopefully, the Electoral Act amendment bill upon being signed into law, will introduce more reforms. Some of the recommendations contained in the Uwais Committee include

i. A constitutional amendment that will remove INEC from under Executive influence. NJC was recommended to be the body to appoint and compose its members and its funding coming from the Consolidated Revenue.

ii. The functions of Police officers on Election Day as stated in the Police Service Commission guidelines should be enacted into the Police Act.

iii. Election cases should have time limit and a Special Electoral Offences Commission also set up to try electoral offenders.

iv. Anyone against whom an electoral petition has been entered against must not be sworn in till his case was dispensed with and in his favour.

v. More tribunals should be set up in each state etc.

But it's with dismay that this research announces that none of these recommendations has so far been adopted, hence we are still where we are. The researcher hopes that that the electoral amendment bill lying at the president's desk incorporates these recommendations.

\subsubsection{Modernized Voting System in Nigeria}

During the industrial revolution, those who owned businesses and commercial ventures were the richest, but in this technology era, any business run in dissonance with technology will not yield as much profit as those done with the help of technology. This means that the global economy as of today is governed by the precepts of technology. A cursory study at weak and strong economies will show that the former is usually found in countries with low technology and the latter is evident in countries with high technology. Elon Musk the CEO of Tesla Motors and Space X whose networth sits chiefly at \$236.8B could not have achieved this fear if his chain of businesses were not based on technology.

Given the establishment that technology makes things easier for people and it's in conformity with world standard practices, INEC is adviced to adopt it in the conduct of Elections. Our society is prone to violence and it becomes pervasive during Election period, hence electronic casting and counting of voters has become inevitable. If our enabling laws on Elections are adjusted in this regard, it will enable Nigerans in diaspora, in prison confinement, hospitals etc; to vote so far as they have an internet enabled gadget.

\subsection{Remedies to Electoral Challenges in Nigeria}

Quite a number of solutions have been proffered regarding the problems bedeviling the Nigeran Electoral System in Nigeria. However the most important which encapsulates all varieties of problems and tends to solve them is the Uwais Electoral Reform Committee Report. That report acts like a since dose that cures varieties of ailments. That report has several recommendations, some of which have been reproduced in under paragraph 4.2 above. If that report is implemented, INEC can no longer be influenced or controlled remotely by those holding executive powers. This means, power of incumbency has been whittled down. Again, the police can no longer be

\footnotetext{
${ }^{1} \mathrm{~S}$. Uwhejevwe-Togbolo, 'Problems of Elections in Nigeria' http://www.gamji.com Accessed $14^{\text {th }}$ December, 2021

2 Some of the factors identified by that document include weak enforcement laws, weak institutions, poverty, corruption etc.

3 D. Arowolo, Electoral Reforms, Good Governance and Sustainable Development in Nigeria, 5 (12) International Journal of Sustainable Development (2013),11-18 at 13
} 
used to rig elections or intimidate opposition members. Since a person would not be sworn in until matters against him has been dispensed with, he cannot use money from state coffers to bribe and influence court decisions in his favour.

We still have problems and challenges bedeviling the Nigerian Electoral System because the Uwais Committee Report which promises to being lasting solution to Electoral conundrums was neglected. It's time to go back to the drawing board and have it implemented.

In addition to Uwais Electoral Reform Committee Report, Electronic voting should be statutorily adopted, this will remove the hitches experienced during voting manually at policing units. This will reduce ballot box snatching or intimidation.

INEC should be made to uphold the principle of voters' education. They will take steps to go to the nooks and crannies of the nation to sensitize Nigerians, especially those perceived as ignorant and uneducated about the importance and benefits of participating in elections. This will go a long way to cure the ailment of voters' apathy.

\subsection{Conclusion/Recommendations}

Most of the elections conducted in Nigeria always have one complain or the other. Thus each time election is to be conducted, there are usually intra party complains of godfatherism and imposition of candidates. At the general level, news of assassination, intimidation, violence, ballot box snatching, rigging etc. begins to inundate the airwaves. It's also noted with dismay that voters usually are not interested to vote, even most of those who come out to vote insist that their votes must be bought.

The elections in Nigeria have legislative backing and this affords the electoral activities legitimacy. Thus anything in these activities which is short of legislative stipulations is regarded as invalid. Some of these legal framework are The Constitution, Electoral Act etc. The laws as identified above also created some institutional bodies and saddled them with the responsibility of either conducting and supervising elections or adjudicating petitions that arise therefrom. Some of these institutions are INEC, SIEC, Political Parties and the Courts.

On the part of the commission, they have inadequate staff and are reluctant to conduct voters' education. The commission finds it difficult to register eligible voters and issue them with PVC. The Commission chooses to begin registration and issuance of PVC a month or two months away from the date of Election. This causes so much problems because they definitely cannot attend to everybody within that short period. The Commission also lacks technology to make voting easier and even if it adopts technology today, the available legal framework will operate as stumbling blocks. This is because e-voting is unknown to our Electoral Jurisprudence. An example is the case where actions brought on noncompliance with card reader failed because the Electoral Act did not recognize it.

Having identified the different issues affecting the Nigerian Electoral System, this article hereby suggests the following recommendations.

i. Independence of the Electoral Body

The Electoral Body has always been a puppet of the Executive Arm who uses the power and resources at its disposal to bring the former to full submission. The result is that the Electoral Body act at the pleasure of the Executive thus adversely affecting its independence. If the Electoral Body decides to act contrary to the will of he who seats as president, the INEC Chairman is either removed or the institution is starved of funds. It's thus submitted in Uwais Electoral Reform Committee Report that if the Independence of the institution has to be properly guaranteed, the funding of the Electoral Body must come from the Consolidated Revenue funds. This was the Executive will not be the sole financier of the institution, thus whittling down its influence. In the same Uwais Report, it was recommended that the power to appoint INEC Chairman be vested in the NJC. This will reduce to the barest minimum, the influence the Executive has on the body.

ii. Amendment of Legal Frameworks

Some of the laws in Nigeria just are not modelled in a way that free fair and credible election becomes just a verbal rhetoric. For instance, the Independent National Electoral Commission is verbally independent, but practically dependent by the funding as backed by the laws enabling it. The Electoral Act merely established the Independent National Electoral Commission Fund ${ }^{1}$ stating that a prescribed amount shall from time to time be paid into it. From the workability of financial disbursement in Nigeria, it's at the pleasure of the executive. So to ensure total independence, the funding has to be untraceable to the Executive and the appointment done independent of the executive, and all these can only come to fruition if the necessary Acts are amended. Lastly, since all parts of human existence is fast aligning with the use of internet, the Nigerian Electoral System should be legislatively upgraded to have an e-database of voters otherwise known as data register. There should also be the use of internet voting with a space to put ones voting number in order to grant one access to the e-polling unit.

${ }^{1} \mathrm{~s} 3$ of the Electoral Act 2010 
iii. Creation of Special Electoral Offences Commission

The Uwais Electoral Reform Committee Report also recommended that there should be created, the Special Electoral Offences Commission that will act in the like of a court having jurisdiction to try Electoral offenders and ensuring that justice is served. For instance those who brazenly rig elections, carry ballot boxes, disturb or obstruct voters at polling units, commercialization of votes and even Electoral Officers who bend the rules to favour one candidate against the other should be made to be tried by this court.

iv. E-voting

So far the only thing that resembles electronic voting in our Electoral System is the usage of card reader. However, the usage of card reader is flawed because many actions with sought on rely on its incompliance failed ${ }^{1}$. This was because it's not been infused into our corpus juris. Beyond this, the legislature is advised to amend the Electoral Act to comprise of not just card reader, but cyber voting, e-voters' register, e-polling units, to enable those who can't come to the physical polling unit for various reasons, are not disenfranchised.

v. Police

The Police other than thugs has become a willing in the hands of some political overlords to antagonize, bully, intimidate and detain political rivals. So if headway is to be made, the Nigerian Police Act has to be amended to incorporate the guidelines of the Police Service Commission. This will put a strict check on the police officers around polling units. Hence rather than be instrument of mayhem against political rivals, they will remain as security for all.

vi. Education

Training and educational programs can help raise the political awareness, get professionals among electoral staff and political parties and explain to citizens how important each voice is. Only political training can describe the importance and consequences of what can be done, and what is taboo. The masses should be well sensitized and informed about the gains of free and fair elections and the consequences of electoral fraud.

\footnotetext{
${ }^{1}$ Wike V. Peterside \& ors (SC.1002/2015); Atiku Abubakar v INEC ((LER [2019] CA/PEPC/002/2019)).
} 